\title{
MACROLIDE ANTIBIOTICS: THE ANALYSIS OF SOCIO-ECONOMIC AFFORDABILITY
}

\section{N.A.Matyashova, A.I.Yemets}

\author{
National University of Pharmacy
}

Key words: antibiotics; affordability; macrolides; coefficient of the solvency adequacy

\begin{abstract}
The structure of the pharmaceutical market of macrolide antibiotics in Ukraine has been analyzed; the coefficient of the solvency adequacy has been calculated within the period of 2012-2014. The analysis of the range of drugs and their socio-economic affordability was conducted during 2012-2014 according to the data of Morion Pharmstandard Analytical Market Research System. To conduct the analysis of socio-economic affordability of drugs the coefficient of the solvency adequacy (Ca.s) expressed in the proportion of the average wage spent on the purchase of one drug package has been calculated. According to the data for 2015 macrolide antibiotics are presented in sufficient quality at the Ukrainian pharmaceutical market: 132 TNs taking into account their dosage forms. The number of foreign drugs exceeds domestic supply: 82 and 50 TNs, respectively. The analysis of the pharmaceutical market for 2012-2015 has shown a downward tendency in the total number of offers for macrolides: from 172 TNs in 2012 to 132 TNs in 2015. However, as this study shows, this reduction is solely due to foreign drugs. The number of domestic offers is unchanged over time. Macrolide antibiotics are presented in a wide range, as well as in a various price range, and their high affordability allows patients to choose the drug taking into account its economic opportunities.
\end{abstract}

$\Delta$ t present, the antimicrobial therapy of various infectious diseases is greatly worsened by development of pathogen resistance. This situation can be seen as a threat to the national security and cause great social and economic harm.

Microorganisms cause infectious diseases since the dawn of humanity and continue this process despite the scientific and practical progress in their treatment achieved in most countries of the world. In recent decades the resistance of pathogens to antimicrobial agents has become a serious problem worldwide $[3,6]$.

Macrolides have been widely used in clinical practice for more than half a century and proven themselves as highly effective and one of the safest antibiotics.

Increase in interest to macrolide antibiotics in the 1990s was associated mainly with three important trends that appeared at that time [5]. Firstly, within those years there were numerous studies showing that in several European countries, such as France, Spain and Italy, the resistance of pneumococcus, a major causative agent of respiratory disease, to penicillin increased significantly, and reached $40 \%$ or more of all strains $[2,3]$. At the same time, such a significant change in resistance to macrolides was not reported. And by their clinical efficacy for infectious diseases of the respiratory tract new macrolides did not yield to ampicillin, amoxicillin and oral cephalosporins of the second generation. Secondly, a significant breakthrough in the diagnosis of infections caused by such intracellular pathogens as Chlamydia, Mycoplasma and Legionella, at the end of the 1980s the beginning of the 1990s, as well as the high antibacterial activity of macrolides against them substantially increased the interest in these drugs. Thirdly, there was quite a lot of works showing that macrolides had the mucoregulatory action, a moderate steroidlike effect, as well as the anti-inflammatory and immunoregulatory effect $[2,4]$.

Under conditions of the limited health resources and increase in the population needs in providing quality health care the price characteristics of drugs are of

N.A.Matyashova - Candidate of Pharmacy $(\mathrm{PhD})$, teaching assistant of the Department of Pharmacoeconomics of the National University of Pharmacy (Kharkiv)

great socio-economic value in addition to efficiency and safety indicators. This is due to their direct influence on formation of such an important indicator as affordability of drugs.

The aim of the study was to investigate the range of macrolide antibiotics at the Ukrainian pharmaceutical market and calculate the coefficient of the solvency adequacy in the period of 2012-2014.

\section{Materials and Methods}

The analysis of the range of drugs and their socio-economic affordability was conducted during 2012-2014 according to the data of Morion Pharmstandard Analytical Market Research System [1].

To conduct the analysis of socio-economic affordability of drugs the coefficient of the solvency adequacy (Ca.s) expressed in the proportion of the average wage spent on the purchase of one drug package was calculated. Calculations were performed using the formula:

$$
\text { Ca.s. }=\text { P/Wa.w. } \times 100 \% \text {, }
$$

where: Ca.s. - is the coefficient of the solvency adequacy;

$\mathrm{P}$ - is the average retail price of one drug package per year;

Wa.w. - is the average wage per year. 


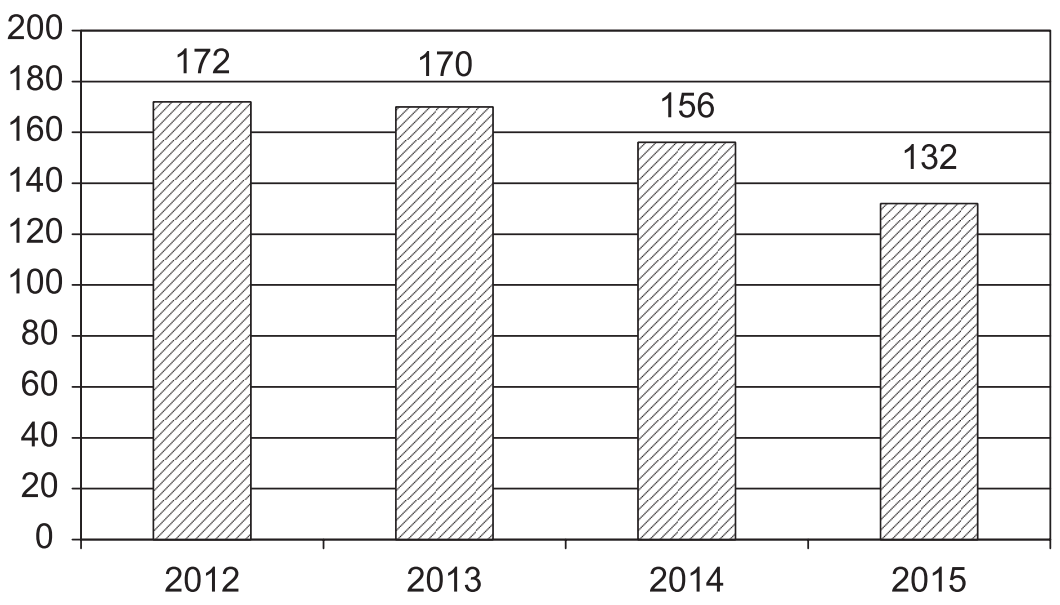

Fig. 1. The number of TNs of macrolides for 2012-1015

To assess affordability the following scale was used: Ca.s $\leq 5 \%-$ highly affordable; Ca.s $>5 \%<15 \%$ of average affordability; Ca.s $\geq 15 \%$ of low affordability.

The level of the average wage was taken according to the data of the State Statistics Service of Ukraine (www.ukrstat.gov.ua).

\section{Results and Discussion}

In 2015, 132 TNs (including dosage forms) of macrolides on the basis of 7 INNs were registered in Ukraine, and among them 38\% domestic ones and $62 \%$ - foreign ones.

In the analysis of the data of the pharmaceutical market of macrolide antibiotics in the period from
2012 to 2015 there was a downward tendency in the number of both foreign and domestic drugs: from 172 TNs in 2012 to 132 TNs in 2015. The results are shown in Fig. 1.

During the period studied there was decrease in foreign TNs (from 123 TNs in 2012 to 82 in 2015). The number of domestic TNs is virtually unchanged over time (Fig. 2).

In 2015 the market of macrolides was presented by 74 manufacturers, among which there were 62 foreign and 12 domestic companies. The leaders among the manufacturers by the number of macrolides produced are Teva (Israel), Sandoz (Switzerland), Zdorovye Group of Companies (Ukraine, Kharkiv).
The price range for 2015 was from UAH 5.31 to UAH 799.57. The cheapest drug was Erythromycin produced by Sopharma (Bulgaria), enteric-coated tablets, $100 \mathrm{mg}$, in blister, No.10, and ROXID 150, Alembic Ltd. (India), film-coated tablets, $150 \mathrm{mg}$, No.100 was the most expensive.

The next stage of our research was to analyze the socio-economic affordability of macrolide antibiotics at the Ukrainian pharmaceutical market for 2014. To conduct the analysis the standard course of the antibiotic therapy using a daily dose of the drug (depending on the active substance) and the 10-days course of treatment were calculated for each drug. The data are given in Table.

According to the data by Ca.s min obtained the group of drugs with low affordability included drugs on the basis of Josamycin, the group of drugs with average affordability - on the basis of Spiramycin, and the group of highly affordable drugs included drugs on the basis of Erythromycin, Midecamycin, Roxithromycin, Clarithromycin and Azithromycin.

By Ca.s max drugs with low affordability were Spiramycin, Midecamycin, Josamycin, Clarithromycin and Azithromycin. The drugs

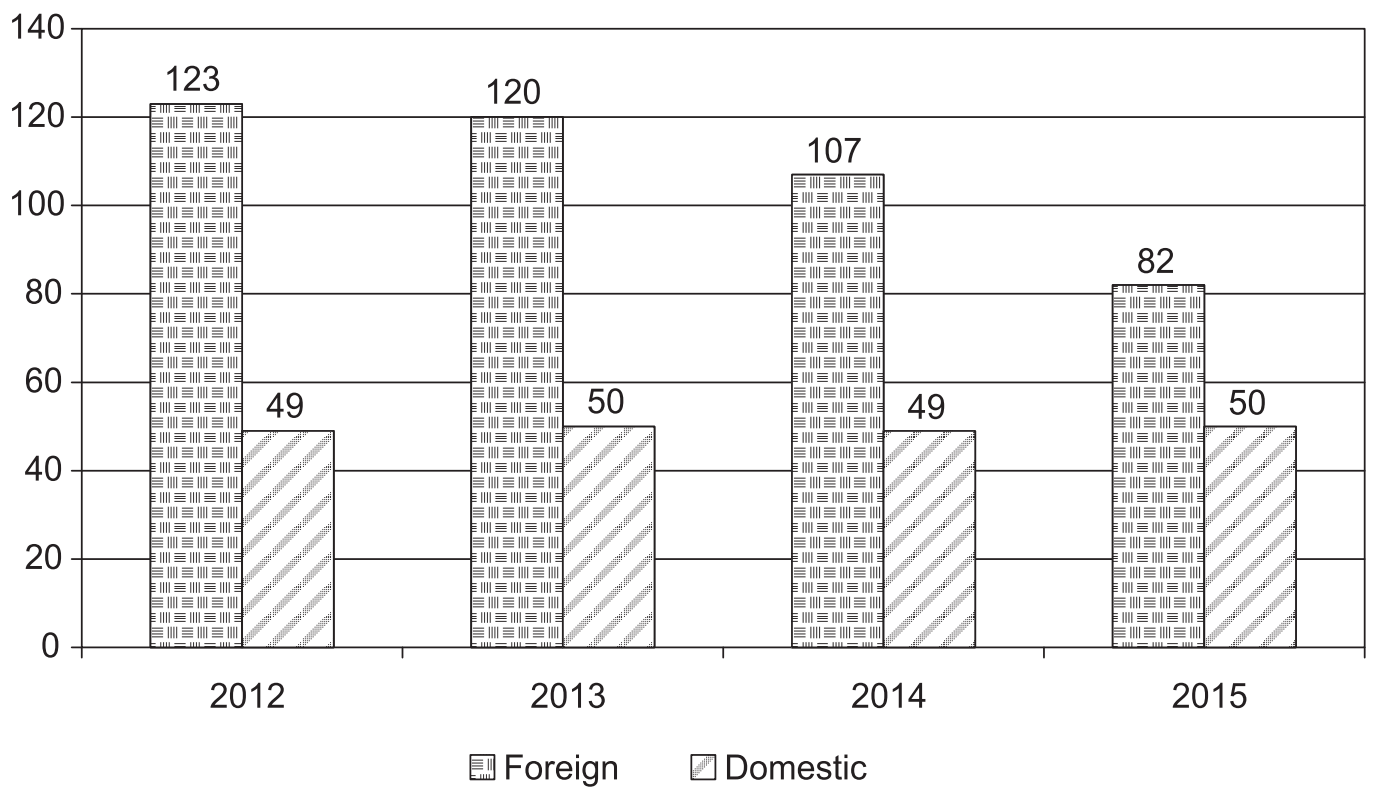

Fig. 2. The proportion of foreign and domestic TNs for 2012-2015 
Table sented in sufficient quality at the

\section{Analysis of the affordability ratio of macrolide antibiotics}

\begin{tabular}{|l|c|c|c|c|}
\hline \multicolumn{1}{|c|}{ INN } & $\begin{array}{c}\text { min cost per } \\
\text { package, UAH }\end{array}$ & $\begin{array}{c}\text { max cost per } \\
\text { package, UAH }\end{array}$ & Ca.s. min, \% & Ca.s. max, \% \\
\hline Erythromycin & 4.59 & 21.45 & 1.25 & 5.96 \\
\hline Spiramycin & 87.36 & 161.46 & 13.22 & 83.20 \\
\hline Midecamycin & 49.12 & 50.31 & 2.92 & 15.97 \\
\hline Roxithromycin & 17.59 & 433.96 & 2.76 & 3.35 \\
\hline Josamycin & 282.75 & 282.75 & 17.95 & 17.95 \\
\hline Clarithromycin & 19.58 & 351.62 & 1.51 & 71.04 \\
\hline Azithromycin & 4.25 & 508.71 & 0.45 & 64.03 \\
\hline
\end{tabular}

on the basis of Erythromycin were included in the group of drugs with average affordability, and only drugs on the basis of Roxithromycin remained in the group of highly affordable drugs.

The study has shown that at the Ukrainian pharmaceutical mar- ket most macrolide antibiotics are highly affordable for customers, and it creates the opportunity to choose the drug for a patient depending on his/her income.

\section{CONCLUSIONS}

1. According to the data for 2015 macrolide antibiotics are pre-
Ukrainian pharmaceutical market: 132 TNs taking into account their dosage forms. The number of foreign drugs exceeds domestic supply: 82 and 50 TNs, respectively.

2. The analysis of the pharmaceutical market for 2012-2015 has shown a downward tendency in the total number of offers for macrolides: from $172 \mathrm{TNs}$ in 2012 to 132 TNs in 2015 . However, as this study shows, this reduction is solely due to foreign drugs. The number of domestic offers is unchanged over time.

3. Macrolide antibiotics are presented in a wide range, as well as in a various price range, and their high affordability allows patients to choose the drug taking into account its economic opportunities.

\section{REFERENCES}

1. Программный комплекс «Аптека» компании «Морион» [Електронний ресурс] - Режим доступу: http: //pharmbase.com.ua/poisk/.

2. Critchley I.A., Brown S.D., Traczewski M.M. et al. // Antimicrob. Agents Chemother - 2007. - Vol. 51 (12). - P. 4382-4389.

3. Jenkins S.G., Brown S.D., Farrell D.J. // Ann. Clin. Microbiol. Antimicrob. - 2008. - Vol. 7. - P. 1.

4. Jenkins S.G., Farrell D.J. // Emerg. Infect. Dis. - 2009. - Vol. 15 (8). - P. 1260-1264.

5. Sahm D.F., Brown N.P., Draghi D.C. et al. // Postgrad. Med. - 2008. - Vol. 120, №3 (Suppl 1). - P. 8-15.

6. Sahm D.F., Brown N.P., Thornsberry C. et al. // Postgrad. Med. - 2008. - Vol. 120, №3 (Suppl 1). - P. 16-24.

\section{АНТИБАКТЕРІАЛЬНІ ПРЕПАРАТИ ГРУПИ МАКРОЛІДІВ: АНАЛІЗ СОЦІАЛЬНО-ЕКОНОМІЧНОЇ ДОСТУПНОСТІ}

Н.А.Матяшова, А.І.ємець

Національний фармацевтичний університет

Ключові слова: антибактеріальні препарати; доступність; макроліди; показник адекватності платоспроможності

Проаналізована структура фармацевтичного ринку антибіотиків групи макролідів в Україні та розрахований показник адекватності платоспроможності в динаміці за 2012-2014 рр. Аналіз асортименту лікарських засобів і їх соціально-економічної доступності проводився за даними аналітичної системи дослідження ринку «Фармстандарт» компанії Моріон за 2012-2014 рр. Для аналізу соціально-економічної доступності ЛЗ розраховували показник адекватності платоспроможності (Са.s.), який виражається в частці середньої заробітної плати, що витрачається на придбання однієї упаковки ЛЗ. Антибіотики групи макролідів на фармацевтичному ринку України за даними 2015 р. представлені в достатній кількості: 132 ТН з урахуванням ЛФ. Кількість препаратів імпортного виробництва перевишує вітчизняні пропозиції: 82 і 50 тН відповідно. Аналіз фармацевтичного ринку за 2012-2015 роки показав тенденцію до зниження загальної кількості пропозицій макролідів: з 172 Тн у 2012 році до 132 Тн у 2015 році. Однак як показало дане дослідження, це зниження відбувається виключно за рахунок імпортних препаратів. Кількість вітчизняних пропозицій незмінна з плином часу. Антибіотики групи макролідів представлені в широкому асортименті і в різному ціновому діапазоні, а висока доступність дозволяє пацієнтам вибрати препарат з урахуванням їх економічних можливостей. 


\section{АНТИБАКТЕРИАЛЬНЫЕ ПРЕПАРАТЫ ГРУППЫ МАКРОЛИДОВ: АНАЛИЗ СОЦИАЛЬНО-ЭКОНОМИЧЕСКОЙ ДОСТУПНОСТИ}

Н.А.Матяшова, А.И.Емец

Национальный фармацевтический университет

Ключевые слова: антибактериальные препараты; доступность; макролиды; показатель адекватности платежеспособности

Проанализирована структура фармацевтического рынка антибиотиков группы макролидов в Украине, рассчитан показатель адекватности платежеспособности в динамике за 2012-2014 г2. Анализ ассортимента лекарственных средств и их социально-экономической доступности проводился в течение 2012-2014 годов по данным аналитической системы исследования рынка «Фармстандарт» компании Морион. Для анализа социально-экономической доступности лекарственных препаратов рассчитывали показатель адекватности платежеспособности (Са.s.), который выражается в доле средней заработной платы, расходуемой на приобретение одной упаковки ЛС. Антибиотики группы макролидов на фармацевтическом рынке Украины по данным 2015 г. представлены в достаточном количестве: 132 ТН с учетом ЛФ. Количество препаратов импортного производства превышает отечественные предложения: 82 и 50 Тн соответственно. Анализ фармацевтического рынка за 2012-2015 годы показал тенденцию к снижению общего количества предложений макролидов: со 172 ТН в 2012 году до 132 ТН в 2015 году. Однако как показало данное исследование, это снижение происходит исключительно за счет импортных препаратов. Количество отечественных предложений неизменно с течением времени. Антибиотики группы макролидов представлены в широком ассортименте и в различном ценовом диапазоне, а высокая доступность позволяет пациентам выбрать препарат с учетом их экономических возможностей.

Address for correspondence:

Received in 11.05.2016

4, Valentynivska str., Kharkiv, 61168, Ukraine.

Tel. (572) 65-88-95. E-mail: feknfau@ukr.net.

National University of Pharmacy 